\title{
Susceptibility of fabrics in office furniture to microbial attack: microbial burden and health implications
}

\author{
LO Egwari, MI Oniha, OO Ayepola \\ From 3rd International Conference on Prevention and Infection Control (ICPIC 2015) \\ Geneva, Switzerland. 16-19 June 2015
}

\section{Introduction}

Hygiene is advocated as major in the control of infectious diseases; however an area of neglect is furniture we come in contact with daily. Furniture is made of diverse materials; wood, glass, metals, plastics, rubber, clothing fabrics or their combinations. Colonization of furniture made from different types of material and possible health implications are reported.

\section{Objectives}

We investigated the associated health risk in the use of furniture made from different materials.

\section{Methods}

The office setting was used and tables and seats were sampled for presence and burden of microorganisms. Also visual inspection was made for evidence of microbial attack and degradation of fabrics. Degree of susceptibility of different materials in furniture was assessed. Sampling was done after the surface was wiped with dry cloth and after cleaning with detergent solution only and in addition disinfectant.

\section{Results}

Rubber fabrics were more susceptible to colonization while metal surfaces were least. Fungi were the predominant colonizers especially, Penicillium and Aspergillus species. Candida spp were isolated in $14 \%$ of the furniture sampled. Bacteria diversity included the Gram positive and Gram negative, but particular were the preponderance of Pseudomonas, Proteus, and Klebsiella. The use of dry cloth to wipe the surface had negligible role in reducing the burden of colonizing organisms. Cleaning with detergent solution reduced microbial burden by $35 \%$ while application of disinfectant yielded $90 \%$ reduction. Clothing fabric haboured more microorganisms but showed no visual signs of microbial attack.

\section{Conclusion}

Furniture may serve as a pool for breeding pathogenic organisms if not properly maintained. Regular cleaning with detergent and disinfectant is advocated.

\section{Disclosure of interest}

None declared.

Published: 16 June 2015

\section{doi:10.1186/2047-2994-4-S1-P36}

Cite this article as: Egwari et al: Susceptibility of fabrics in office furniture to microbial attack: microbial burden and health implications. Antimicrobial Resistance and Infection Control 2015 4(Suppl 1):P36.

Submit your next manuscript to BioMed Central and take full advantage of:

- Convenient online submission

- Thorough peer review

- No space constraints or color figure charges

- Immediate publication on acceptance

- Inclusion in PubMed, CAS, Scopus and Google Scholar

- Research which is freely available for redistribution 